\title{
Urgency of Changes in Structure and Governance in the Downstream Oil and Gas (BPH MIGAS) Regulatory Agency as an Independent Institution
}

\author{
Paramita Prananingtyas ${ }^{1}$, Irawati ${ }^{2}$, Normalita Destyarini ${ }^{3}$, Alifah Nur Fitriana Naridha ${ }^{4}$ \\ \{pptyas@live.undip.ac.id ${ }^{1}$ \} \\ Universitas Diponegoro, Indonesia ${ }^{1,2,3,4}$
}

\begin{abstract}
BPH Migas as the Agency that has the authority to regulate the downstream oil and gas business in Indonesia, in its implementation there are obstacles both in terms of conducting supervision and the internal organizational structure of BPH Migas. Obstacles in carrying out supervision in the form of technical and resources. As well as problems in the form of position as an independent institution in supervising downstream oil and gas business. This study aims to determine the independence of BPH Migas in regulating the downstream oil and gas agency and the governance of the BPH Migas organizational structure in regulating Indonesia's downstream businesses. Through an empirical juridical approach, this empirical legal research concludes that, The independence of BPH Migas has not been implemented as mandated by Law Number 21 of 2011 as an independent body, as emphasized in the provisions of Article 2 paragraph (2) of Government Regulation Number 67 of 2002 which states that the regulatory agency is formed to regulate and supervise the supply and distribution of Oil and Gas Fuel through pipelines in Downstream Business Activities which is a government institution that carries out its functions, duties and authorities independently and is not influenced or separated from the influence and power of the government as well as other parties. This is evidenced by the decision making by the Head of the Governing Body, the committee must make decisions by agreement with the Committee Members, so that GCG implementation is needed in the form of transparency in the decision-making process for the Committee Chair, Director at the Directorate and Secretary to the Governing Body. Therefore, there is a need for a decision instrument that has separate rules for the Directorate in carrying out its duties and has regulatory guidelines not derived from the discretion of the Committee's decisions.
\end{abstract}

Keywords: BPH Migas, Independence, Downstream Business

\section{Introduction}

Global developments and challenges in the future, oil and gas business activities in Indonesia are required to enhance further their capabilities in supporting the continuity of national development to increase the prosperity and welfare of the people. The oil and gas industry is an industry that is capitalized (high cost), technology-intensive (high technology), risk intensive (high risk) [1][2][3]. Oil and natural gas are strategic non-renewable natural resources controlled by the state and are vital commodities that play a vital role in supplying industrial raw materials, meeting domestic energy needs, and an important source of foreign exchange. It requires optimal processing so that it can be used for the greatest prosperity and welfare of the people. 
The importance of oil and gas policies in managing hydrocarbon resources is based on the awareness that: a). The amount of oil and gas reserves is minimal; b). Oil and gas are nonrenewable resources; c). The existence of hydrocarbon reserves on earth is uneven; d). Environmental disturbance; e). Oil and gas are one of the most important energy sources in the world; f). Oil and gas are foreign exchange sources [1].

Based on the provisions of Law Number 20 of 2001, Oil and Gas are strategic nonrenewable natural resources in the Indonesian Legal Mining Territory. They are national assets controlled by the state. The Government holds control by the state as the Mining Authority holder. In Law Number 22 of 2001, the government divides' Indonesia's energy sector's management into two parts: the upstream and downstream sectors. The upstream sector deals with exploration and exploitation, while the downstream sector regulates the oil and gas trade (Law 22 of 2001, article 5) [4].

The production sector in the national oil and gas industry is referred to by Law Number 22 of 2001 as the "upstream sector", including the exploration and exploitation processes. The oil and gas industry has been the mainstay of state income since the 'oil boom' era of the 1970s. Post-reform, Indonesia regulated the Oil and Gas industry with Law Number 22 of 2001 on Oil and Natural Gas. This law later became the legal umbrella for implementing the Oil and Gas industry in Indonesia. With the enactment of Law Number 22 of 2001, the implementation of oil and natural gas business activities from a philosophical aspect underwent a fundamental change. The Government was the policyholder in the oil and natural gas sector. In this connection, for downstream business activities, the government considers it necessary that in order to guarantee the interests of the government, investors, producers, and consumers in certain activities, namely the supply and distribution of Oil Fuel and the transportation of Natural Gas through pipes, a Regulatory Agency for the Supply and Distribution of Oil Fuel and Business Activities is established. According to Nurtjahjo [5], the objective of establishing this independent state institution was due to two things, namely: Due to increasingly complex state tasks that require sufficient independence for their operations and efforts to empower existing state institutions' tasks by forming new, more specific institutions. Also mentioned in the provisions of Article 8 paragraph (1) Government Regulation Number 67 of 2002 states that the Regulatory Body is responsible to the President and Article 8 paragraph (2) states that the Head of the Regulatory Agency is obliged to provide a report to the President through the Minister regarding the results of his work periodically every 6 (six) months and/or if necessary.

The task of BPH oil and gas is to ensure the availability and smooth distribution of Oil Fuel as a vital commodity and to control the lives of many people in the Republic of Indonesia, to regulate and determine and supervise the availability, distribution, reserves of Oil Fuel nationally and to regulate and supervise the implementation. The supply and distribution of Oil Fuel and the transportation of natural gas by pipeline are conducted by a business entity that has obtained a permit from the Minister. With Presidential Decree Number 86 of 202, then BPH Migas as the implementer, can carry out the regulation's objectives through concrete actions. With a vision that is in the form of the realization of the supply and distribution of BBM throughout Indonesia and an increase in the use of Natural Gas in the country through fair, healthy, and transparent business competition for the prosperity of the people. BPH Migas's mission is to realize its vision in the form of independent and transparent regulation and supervision of the implementation of business activities for supplying and distributing BBM and increasing the use of Natural Gas in the country.

The constraints experienced by BPH Migas related to independence in carrying out its duties have made the author examine the independence of BPH Migas in overseeing 
downstream business activities and the organizational structure required by BPH Migas in supporting the implementation of its duties and functions.

\section{Research Methods}

This article's approach method is juridical empirical, emphasizing the enactment or implementation of normative legal provisions in action at any particular legal event that occurs in society with the research specification in the form of descriptive-analytical. The type of data in this article uses qualitative data obtained based on primary data sources collected through interviews, namely a conversation, a question and answer session between the researcher and the respondent who sits physically facing each other and is directed to a particular problem [6][5][7]. Secondary data consists of primary legal materials, secondary legal materials, and tertiary legal materials. This article's data collection method is carried out through field studies conducted by interviewing sources at BPH Migas, especially in the Legal and Public Relations section who can provide all information related to the functions and duties of BPH Migas in downstream business activities. Furthermore, the data were analyzed using qualitative analysis methods.

\section{Results and Discussion}

\subsection{Independency of BPH Migas in Regulating the Downstream Oil and Gas Agency}

The current independence of BPH Migas as a regulatory body is a technical regulator because the technical policy regulator at the Directorate General of Oil and Gas regulates from upstream and downstream to implementing fuel quality specification standards. The task as a supervisory body still requires adequate organizational structure support, employees who have the status of ASN as employees under the Ministry of Energy and Mineral Resources, related to decisions must be strengthened by regulatory instruments to carry out their duties. However, in practice, there is more discretion in committee decisions. The changes required for BPH Migas professionally and independently are carried out by responding to the influence of the external environment and the internal environment to direct changes following the organization's vision. The underperformance of BPH Migas is due to the law's authority due to the absence of a Special Directorate in charge of supervising and facilitating law enforcement and centralized supervision of BPH Migas without a regional representative office.

According to Greiner [8], each evolutionary period is characterized by a dominant management style, and each revolution is characterized by a dominant management problem that must be resolved if the organization is to continue to grow. One of which is Growth through direction leading to a crisis of autonomy: During the second phase of growth, organizations often differentiate activities and develop a functional organizational structure, along with a clear hierarchy, more formal communication systems, and more sophisticated accounting, inventory and manufacturing systems. Although this new level of order and direction delivers efficiencies, as the organization continues to grow, it eventually becomes less effective; for example, long 
communication chains delay decision making and set procedures prevent competent people taking initiatives. This leads to demands for greater autonomy [9].

As an independent institution, the Regulatory Body needs to apply the principles of Good Corporate Governance (GCG). As a company that must have good governance, healthy management can emerge. In general, GCG can be understood as a corporate governance system that contains a system of rules regarding good and correct corporate governance. This GCG principle is also felt to apply to the Downstream Oil and Gas Regulatory Agency.

Sedarmayanti [10] defines corporate governance as a system, process, and set of regulations that regulate the relationship between various interested parties, especially in the narrow sense, the relationship between shareholders, the board of commissioners, and the board of directors for the achievement of organizational goals. More narrowly, the term corporate governance is used to describe the board of directors' roles and practices. In other words, company management is related to the relationship between company managers and shareholders, which is based on the view that the board of directors is an agent of shareholders to ensure a company is well managed for the benefit of the company [11]. GCG is the principle that underlies the company's management, prevents significant corporate strategy errors, and ensures that errors that occur can be immediately corrected [10]. The management principle of this company can be applied to the Downstream Oil and Gas Regulatory Body to support the institution's independence.

Basically, the most essential of Good Corporate Governance is a system or device that regulates the relationship between all parties involved in an organization [10]. In contrast to Corporate Governance, which only emphasizes corporate governance, the implementation of which is the keyword for creating a healthy company. However, its implementation requires a problematic effort.

The principles of GCG according to Article 3 Copy of the Regulation of the Minister of State for State-Owned Enterprises Number per-01/MBU/2011 concerning the Implementation of Good Corporate Governance in State-Owned Enterprises include (1) transparency as openness in carrying out decision making and in presenting material and relevant information [12][13], (2) accountability is a principle whereby managers are obliged to develop an effective accounting system to produce reliable financial statements [14], independence and fairness.

Furthermore, in the GCG discussion, there are 2 (two) main theories that become references in building good corporate governance that can be applied to the Oil and Gas Downstream Regulatory Body. The first theory is the stewardship theory, built on the assumption that humans are basically people who can be trusted, have integrity, act according to the owner's interests, and are responsible. So that in its position as an independent institution in implementing accountability, transparency, and responsibility in the future, it can expand democracy [15][16]. Agency theory views that company management basically acts as an agent for shareholders. An agent's concept can be understood as a person who is given the power by another person (the principal) to enter into an agreement with a third party on behalf of the principal [17]. It can be said that the actions of the company management are carried out with full awareness of the interests of shareholders. However, agency theory has also produced an important way of explaining manager's and owners' conflicting interests, which is a hindrance [15].

\subsection{Organizational structure governance of BPH in regulating downstream businesses in Indonesia}

The Downstream Oil and Gas Regulatory Body is an independent institution with an organizational structure consisting of committees and directorates. Where that the directorates 
consist of directorates and secretaries of regulatory BODIES. The Committee has a vital role in the Governing Body. Because the committee has multiple roles, the Committee Chairman, who is also the Head of the Governing Body to make decisions, must still be done collegially. It is stated in Article 27 of Government Regulation Number 49 of 2012. As the Head of the Regulatory Body, the Committee cannot immediately make decisions without the Committee Members' agreement. The Chairman of the Committee's decision as Head of the Governing Body depends on the majority votes of the members present. So that transparency is needed in the decision-making process for the Committee Chair. Director at the Directorate and Secretary of the Regulatory Body is filled with structural positions at echelon IIa, Head of Sub-directorate and Head of Section are echelon III.a while Head of Section and Head of Subdivision are structural positions at echelon IV.a. Regulation of the Minister of Energy and Mineral Resources Number 25 of 2012 concerning the Organization and Work Procedure of the Secretariat and Directorate at the Regulatory Agency for the Supply and Distribution of Oil Fuel and Business Activities of Transportation of Natural Gas by Pipe is a mandate of Article 15A of Presidential Decree Number 86 of 2002 concerning the Establishment of a Regulatory Agency for the Supply and Distribution of Materials Oil Fuel and Natural Gas Transportation Business Activities by Pipes as amended by Presidential Regulation Number 45 of 2012. The Secretariat and Directorate's organization and working procedures in this Regulatory Body shall be determined by the Minister of Energy and Mineral Resources after obtaining written approval from the Minister in charge of government affairs. In the field of empowering the state apparatus and reforming the bureaucracy. So, it can be seen that the organizational structure contained in the Regulatory Body is still departing from the ESDM Ministerial Regulation.

The implementation of the duties and powers of the Head of the Regulatory Body by conducting regulatory body meetings as contained in Article 8 of the BPH Migas Regulation, the types of meetings that are held are: a) Committee meeting; b) Committee Session; c) Public Hearing; and d) Committee Council Meeting.

The decision-making mechanism is carried out when a committee meeting is held as the highest committee meeting chaired by the Committee Chair can be carried out openly or privately. It is the highest forum in making Committee decisions in regulating, stipulating, and monitoring the duties and functions of the Governing Body, attended by Committee members, Secretariat and Directorate at committee meetings if necessary. Decisions are made collegially, which is endeavored by deliberation to reach consensus; decisions are made based on the Committee Members' majority votes who are present if consensus is not reached. If the majority vote is not achieved, the session's agenda is rescheduled. Decisions of the Committee Session are decisions of the regulatory body that must be signed by the Head of the Agency, who is concurrently the Chair of the Committee. It is stated in Article 10 of BPH Migas Regulation Number 5 of 2015 concerning Procedures for Implementing Duties and Authorities of the Committee for the Downstream Oil and Gas Regulatory Body. Decision instruments must be strengthened with regulatory instruments. In simple terms, the Directorate General institutions, each section or sub-directorate, are expected to have their own rules to carry out their duties, to carry out their business processes. However, nowadays, the Committee is more concerned with discretionary decisions. 


\section{Conclusion}

The independence of BPH Migas in regulating downstream oil and gas bodies is contained in Law Number 21 of 2011, which mandates that it is an independent body by emphasizing the provisions of Article 2 paragraph (2) of Government Regulation Number 67 of 2002, which states that the regulatory body is formed to regulate and Supervision of the supply and distribution of Oil and Gas Fuel through pipelines in the Downstream Business Activities, which is a government institution that carries out its functions, duties, and authorities independently, not influenced or separated from the influence and power of the government and other parties. The organizational structure consists of Committees and Areas referred to in Article 47 paragraph (3) Law Number 22 of 2001 j.o. Article 11 paragraph (2) PP Number 67 of 2002 that the Chairperson and Committee Members are appointed and dismissed by the President after obtaining the DPR's approval based on the minister's proposal. The use of the term Independent State Institutions in Indonesia does not yet have a juridical justification, compared to the United States, which calls independent State institutions Independent Regulatory Agencies (IRAs). The indicators used in analyzing the phenomenon of IRAs in England, France, Germany, and Italy are the extent to which there is politicization in determining the IRAs' leadership, dismissal of IRAs members before the end of their term of office. The longer their tenure, the greater their independence from elected officials, independence in finance and management. The resources and use of power to override decisions/policies issued by the IRAs. Therefore, as an independent institution, it is necessary to apply Good Corporate Governance (GCG) principles as corporate governance that contains excellent and correct corporate governance patterns. It is considered applicable in the Downstream Oil and Gas Regulatory Agency.

GCG principles according to Article 3 Copy of the Regulation of the Minister of State for State-Owned Enterprises per-01/MBU/2011 concerning the Implementation of Good Corporate Governance in State-Owned Enterprises with Transparency, Accountability, Accountability, Independence, Fairness. As independence bodies responsible defining roles and responsible their policy.

The Downstream Oil and Gas Regulatory Body, which in its organizational structure consists of committees and fields, each of which consists of directorates and a secretary of the regulatory body. The role of the committee as Head of the Governing Body in making decisions collegially based on Article 27 of Government Regulation Number 49 of 2012 as Head of the Governing Body the committee must make decisions with an agreement with Committee Members, it is necessary to implement GCG in the form of transparency in the decision-making process for the Committee Chair, Director. At the Directorate and Secretary of the Regulatory Agency. Decisions are made when the committee meeting is held as the highest committee meeting; it may be possible for them to be held openly or privately. Decisions are made collegially, which is sought by deliberation to seek consensus based on the majority vote of Committee Members. Therefore, it is necessary to have a decision instrument that makes separate rules for the Directorate in executing its duties and has guidelines for the rules not derived from the discretionary decisions of the Committee. 


\section{Acknowledgements}

The authors are very grateful to the Faculty of Law, Universitas Diponegoro, for all the support and financial assistance from the 2021 fiscal year.

\section{References}

[1] M. Ariyon, “Studi Kebijakan Migas di Indonesia," J. Earth Energy Eng., vol. 1, no. 1, pp. 37-51, 2012.

[2] D. Hartono, W. W. Purwanto, Nurkholis, and I. A. Rum, "Impact analysis of natural gas policy in Indonesia,” Energy Sources, Part B Econ. Planning, Policy, vol. 12, no. 8, pp. 699-706, 2017.

[3] A. M. Hutagalung, D. Hartono, M. J. Arentsen, and J. C. Lovett, "Economic implications of domestic natural gas allocation in Indonesia," Int. J. Energy Sect. Manag., 2019.

[4] A. R. M. Umar, "Ekonomi Politik Perminyakan Indonesia: Analisis Kebijakan Liberalisasi Sektor Hulu Migas Indonesia pasca-1998,” J. Ilmu Sos. dan Ilmu Polit., vol. 16, no. 1, pp. 45-61, 2012.

[5] H. Nurtjahjo, "Lembaga, Badan, Dan Komisi Negara Independen (State Auxiliary Agencies) Di Indonesia: Tin. Jauan Hukum Tata Negara," J. Huk. Pembang., vol. 35, no. 3, pp. 275-287, 2005.

[6] A. Muhammad, "Hukum dan penelitian hukum." Bandung: Citra Aditya Bakti, 2004.

[7] P. M. Marzuki, "Metode Penelitian Hukum," Jakarta, Kencana, 2005.

[8] R. Greiner, "Factors influencing farmers' participation in contractual biodiversity conservation: a choice experiment with northern Australian pastoralists," Aust. J. Agric. Resour. Econ., vol. 60, no. 1 , pp. 1-21, 2016.

[9] J. Hayes, The theory and practice of change management. Palgrave, 2018.

[10] G. G. Sedarmayanti, "Kepemerintahan yang Baik," Good Corp. Gov. "Tata Kelola Perusah. Yang Baik”, CV Mandar Maju, Bandung, 2012.

[11] M. K. Nasution, "Penelaahan literatur. Teknik Penulisan Karya Ilmiah, 3. Sumatera utara. Researchgate." 2017.

[12] A. Bianchi and A. Peters, Transparency in international law. Cambridge University Press, 2013.

[13] M. Zurn, A. Nollkaemper, and R. Peerenboom, Rule of law dynamics: in an era of international and transnational governance. Cambridge University Press, 2012.

[14] N. Kholidah and T. Mildawati, "Pengaruh Penerapan Prinsip-Prinsip Good Corporate Governance terhadap Kinerja Pegawai," J. Ilmu dan Ris. Akunt., vol. 6, no. 3, 2017.

[15] E. Raharjo, "Teori agensi dan teori stewarship dalam perspektif akuntansi," Fokus Ekon. J. Ilm. Ekon., vol. 2, no. 1, 2007.

[16] S. Tripathi, "Independent Regulatory Authorities: Analysing Accountability, Responsibility and Transparency," Indian J. Public Adm., vol. 64, no. 3, pp. 349-357, 2018.

[17] S. B. Marsh and J. Soulsby, "Business Law (Hukum Perjanjian)." Alumni, Bandung, terjemahan Abdulkadir Muhammad, 1980. 